JURNAL PENDIDIKAN MATEMATIKA DAN IPA

Vol 12, No. 1 (2021) h. 66-72

http://jurnal.untan.ac.id/index.php/PMP

\title{
DESCRIPTION OF MATHEMATICAL REASONING ABILITY ON VOCATIONAL SCHOOL STUDENTS IN SQUARE ROOT MATERIAL
}

\author{
Lailin Hijriani ${ }^{1}$, Susiswo ${ }^{2}$ \\ ${ }^{1}$ Universitas Timor \\ ${ }^{2}$ Universitas Negeri Malang \\ email: elinhijriani@unimor.ac.id
}

DOI: $10.26418 /$ jpmipa.v12i1.44092

\begin{abstract}
The aim of this study is to describe the mathematical reasoning ability of students at TSM major (Motorcycle Engineering) Darul Karomah Singosari on square root material. This study applies descriptive qualitative approach, data was collected using test instrument that has been tested on three research subjects, and analyzed using qualitative descriptive technique. The results show that low-ability (Kemampuan Rendah) subject is the student with less mathematical reasoning ability because the subject has not been able to solve the five existing indicators of mathematical reasoning, middle-ability (Kemampuan Sedang) subject include student with moderate mathematical reasoning ability (although the subject has not fulfilled the five indicators of mathematical reasoning requirements), this can be seen from his effort to make a mathematical assumption even though the conjecture made was not correct, and high-ability (Kemampuan Tinggi) subject refers to the student with high mathematical reasoning ability because he can fulfill two of the five indicators of mathematical reasoning.
\end{abstract}

Keywords: Mathematical Reasoning, Mathematical Reasoning Ability.

Received : 29/12/2020

Revised : 30/12/2020

Accepted : 31/12/2020 


\section{INTRODUCTION}

Learning activities in Math subject are not only about transferring ideas from teacher to students, but more than that. It is a teacher's generosity to let students see, think about, and take advantage of the ideas transferred. Interaction in the learning process is not only tied between teachers and students, rather it is also likely to happen among students or between students and the surrounding environment. Most students have not yet associated themselves with mathematical concepts, because they often assume that learning mathematics is made up of formulas to be memorized. As a result, learning mathematics becomes meaningless (Bernard \& Chotimah, 2018).

The learning process that involves students interpreting an idea has a positive impact on their thinking pattern. This is closely related to students' reasoning in solving a problem. Herman (2007) argues that to be a proficient problem solver, students need to visualize a mental representation of the problem, detect mathematical correlation, and determine new method when it is needed. Students' ability to represent a problem is slightly influenced by the ability of students to do reasoning. NCTM (2000) adds that this significance of reasoning for students, makes it becomes a crucial skill to be developed. This refers to the idea that the reasoning ability practices students to solve complex problem and to use one appropriate solution for the existing problems. Students' reasoning skill can be developed if they are frequently given the opportunity to explore their own abilities. For instance, mathematical reasoning skills can be improved by providing problem-based learning
(Sumartini, 2015). Rosnawati (2013) further points out that mathematical reasoning ability is considered sufficient as a primary requirement for those who want to master mathematics. In the meantime, learning mathematics is all about imitating and memorizing problem solving from the teacher (Mettes, 1979). This misleading learning behavior prevents students from developing their knowledge and skills. One of the efforts to build students' awareness in active learning is by creating a constructive learning atmosphere, bridging discovery, and developing knowledge. It is directly relevant with the opinion of Hijriani (2018) who states that teachers have a great role and responsibility in packaging mathematics to be a more interesting subject. Besides that, teachers are also challenged to create a pleasant learning environment.

An active learning will improve students' reasoning skills. In fact, students' ability in mathematical understanding and reasoning need further attention and improvement. Mathematical reasoning is attributed to a complex and higher level of logical thinking.

Mathematical reasoning ability is directly proportional to comprehension ability (Fuadi, et al., 2016). It can be discerned at students who have good mathematical reasoning, when usually they need less efforts to comprehend a material. Mathematical reasoning does not only practice students to have variety of ways in solving a math problem, but also enables them to decide the best solution among all options.

One of the qualities in learning mathematics is defined by students' reasoning ability. According to Paranduri (2018) the interaction takes 
place among students, learning resources and the teacher determine the quality of learning, while the quality of interaction can be achieved through a pleasant learning atmosphere that triggers an experience. However, students' reasoning skill is going to improve if learning involves students actively and only by the presence of a teacher who acts as both a messenger and a facilitator (Lestari \& Andinny, 2020). The enhancement of students' reasoning skill is at least as important as improving their mathematical skill in general, since it will affect their thinking on solving the problems in everyday life. As stated by Ardana (2007), each individual is embodied with different perceptual and intellectual aspects that make each thinking pattern unique.

Learning that encourages students to be active is different from conventional learning in which placed students as loyal listeners instead of being actively involved in learning. Active learning may include discussions, presentations, questions and answers, and constructive learning methods to stimulate students to be actively involved in the learning process. Mathematical reasoning skills can be improved through Discovery Learning model (Burais, Ikhsan, \& Duskri, 2016). To involve mathematical reasoning ability in learning can be seen in Brain Based Learning (Salim, 2015). A learning model called 'Connecting Extending Review' also plays a role in improving students' mathematical reasoning abilities (Asfar \& Aspikal, 2017).

The importance of a teacher to acknowledge students' ability can affect either strategies or the materials that will be given. In brief, students' mathematical reasoning ability is highly significant because by learning mathematical reasoning, it will have an impact on students' understanding, especially on mathematical material that requires reasoning to solve it. This aims to control and find out what aspects need to be improved (Annizar, et al., 2020). The topics in Math is highly diverse, ranging from simple concepts to a more complex and abstract concepts (Hijriani, et al., 2018). One of them is the square root material which is another form of expressing exponential numbers. The square root is an irrational number that cannot be represented by a fraction $a / b$ with $a$ and $b$ integer elements $b \neq$ 0 (Subchan, et al., 2018). The topic of square root taken is the multilevel square root, where in order to finish the problem, students have to do several steps. Since it took process for a problem to be solved, indirectly, students' tried to comprehend it and started to practice their reasoning skill. Furthermore, Kusumawardani, et al. (2018) as well argue that giving assignments or mathematical problems can enhance students' mathematical reasoning skill. This affects students' attitudes in dealing with problem solving which consequently affects students' to get used to in applying their mathematical reasoning ability.

\section{RESEARCH METHOD}

By applying a qualitative descriptive approach, data was collected using a test question instrument which was given on three students as research subjects. The choice of research subjects are based on non-probability sampling technique (non-random sampling). The students then were grouped into three different levels of ability; low- ability students (KR), medium- ability students (KS), and high-ability students (KT). 
With three subjects in total, each ability represents one category, named as low, medium, and high. This research was conducted at Darul Karomah Singosari Vocational School (SMK) in Malang Regency. From each group category, one student is taken as the research subject. As an initial observation, students were categorized based on their midterm exam scores under the supervision of the teacher who also gave recommendation and suggestion to the researcher.

In this research implementation, the data collection technique used a test question instrument, consisting of several math problems taken from square root material of tenth grade. The subjects in this study were coded as in the following table.

Table 1. of Code Subjects

\begin{tabular}{cl}
\hline $\begin{array}{c}\text { Code } \\
\text { Subjects }\end{array}$ & \multicolumn{1}{c}{ Subjects Ability Level } \\
\hline KR & Low- ability subject \\
KS & Middle- ability subject \\
KT & High- ability subject
\end{tabular}

As for categorizing the mathematical reasoning ability of the subject, the researcher does not strictly focus on the number of instruments must be filled in. Instead, the researcher referred to several reasoning indicators that include; (1) proposing conjectures (formulating various possible solutions to the problems); (2) performing mathematical manipulation (creating examples); (3) providing reasons for the correctness of the solutions obtained; (4) drawing conclusions from the statements or solutions obtained; and (5) finding patterns or styles of mathematical symptoms to create a generalization that if the similar problem is found, it can be solved in the same way (NCTM, 2000).

\section{RESULT AND DISCUSSION}

The results of the three subjects; KR, $\mathrm{KS}$, and KT are as follows.

1. The result of KR

Based on KR work result (Figure 1.), it appears that KR has not been able to solve the problem. KR only completes a part of the total answer to the question. Out of five indicators of mathematical reasoning ability, the subject failed to perform even a single mathematical reasoning ability indicator. Besides of his inability to propose mathematical assumption, the subject also failed to make a mathematical manipulation. KR also did not provide reasons for the correctness of the solutions obtained, did not draw conclusion from the statement and he has not been able to find patterns or properties of mathematical symptoms to make generalization. In short, the work made by KR is still not correct since he provided false solution.

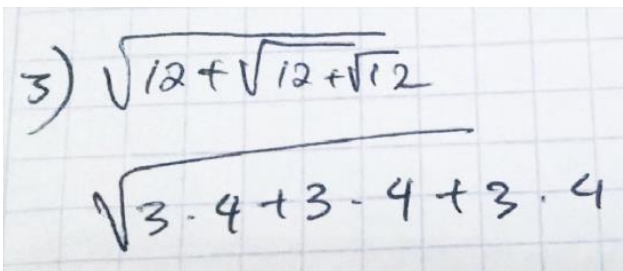

Figure 1. The Result of KR

The result above is in line to the research conducted by Ma'sum (2014) who states that students with low mathematical ability has not been able to comprehend the problem given. They look at the problem but has difficulty in writing down the information and what is actually being asked. This is also relevant to a study conducted by Suprihatiningsih, et al. (2014) who states that students with low mathematical abilities have difficulty understanding the instruction and capturing the question. 


\section{The result of $\mathrm{KS}$}

Based on the work (Figure 2.), KS

has not been able to propose mathematical assumption, has not performed mathematical manipulation, has not provided reason behind the solution, has not drawn conclusion from statements and the last, has not found pattern or style of the mathematical symptoms to be made as generalization.

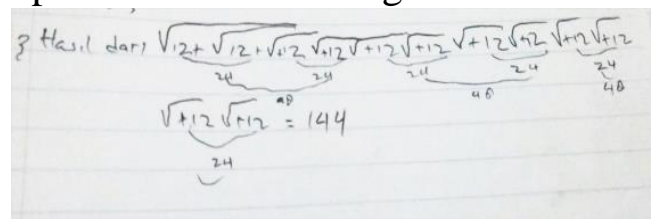

Figure 2. The Result of KS

After looking at KS's work, the result is proved contradictive toward the argument stated by Ma'sum (2014) in his study who points out that students with moderate mathematical abilities have the ability to present problems in both writing and picture correctly. In addition, students with mathematical abilities are supposed to perform mathematical manipulation, to check the correctness of an argument and to draw conclusion from statements. Suprihatiningsih, et al. (2014) further have examined that students with moderate mathematical abilities will be able to understand problems, present mathematical statements and make calculations, but have not arrived at the correct resolution and have not yet come to a conclusion.

Based on the result, KS has not performed mathematical reasoning ability. This is illustrated by the absence of the fulfilled indicators. However, compared to KR, KS's ability to solve the given problem was slightly better. It can be seen from the subject effort to make mathematical assumption even though the allegation was still less accurate.

\section{The result of KT}

Based on KT's work (Figure 3.), mathematical reasoning ability began to appear, even though not all indicators of mathematical reasoning are fulfilled. Firstly, it was indicated that KT has not been able to propose mathematical conjectures. Secondly, as recognized as the next level of accomplishment, the subject created an example to solve the given problem. Thirdly, what promotes the next indicator which providing reasons for the correctness of the solution obtained is the process of accomplishment of the square root problem. In accomplishing the problem, KT only reached the third indicator. The fourth and fifth indicators are missing from the process. Of those five indicators of mathematical reasoning ability, KT fulfilled only two indicators; the second and third indicators.

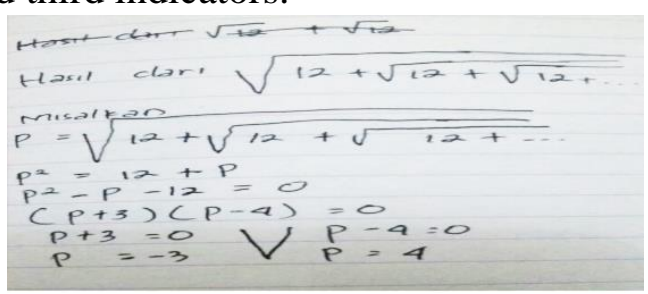

Figure 3. The Result of KT

The results obtained are slightly different from the results of research conducted by Ma'sum (2014) and Suprihatiningsih, et al. (2014) that students with high mathematical abilities have mastered all five indicators of mathematical reasoning. The difference in students 'mathematical reasoning in this study is mainly influenced by their initial abilities. This was proven by the fact that KT has the best mathematical reasoning ability. 


\section{CONCLUSION}

According to the result and discussion, after seeing the works done by $\mathrm{KR}$, KS, and KT subjects, it was suggested that KR subject did not meet any of the five indicators proposed. KR subject is categorized as student who has less reasoning mathematical ability. This is indicated by the absence of even single indicator from the five predetermined indicators. KS subject also did not fulfill any of the indicators, from the first to the fifth. KS is determined to be a student with moderate mathematical reasoning ability. It is because $\mathrm{KS}$ subject is slightly better in analyzing the problem than KR subject. The expected result comes from KT subject who met the second and the third indicators. In conclusion, KT subject is considered to be the student with high mathematical reasoning ability.

\section{REFERENCES}

Annizar, A. M. R., Maulyda, M. A., Khairunnisa, G. F., \& Hijriani, L. (2020). Kemampuan Pemecahan Masalah Matematis Siswa dalam Menyelesaikan Soal PISA pada Topik Geometri. Jurnal Elemen, 6(1), 39-55.

Ardana, I. M. (2007). Pengembangan Model Pembelajaran Matematika Berwawasan Konstruktivis Yang Berorientasi Pada Gaya Kognitif Dan Budaya Siswa (Disertasi tidak dipublikasikan). Surabaya: PPS Universitas Negeri Surabaya.

Asfar, A. I. T., \& Aspikal, A. (2017, November). Pengembangan Model Pembelajaran Berbasis Connecting Extending Review (CER) untuk Meningkatkan Kemampuan Penalaran Matematika. Seminar Nasional Riset Inovatif, 5, 621-630.
Bernard, M., \& Chotimah, S. (2018, September). Improve Student Mathematical Reasoning Ability With Open-Ended Approach Using VBA For Powerpoint. In AIP Conference Proceedings, ( $\mathrm{p}$. 020013), 2014(1) AIP Publishing LLC.

Burais, L., Ikhsan, M., \& Duskri, M. (2016). Peningkatan kemampuan penalaran matematis siswa melalui model Discovery Learning. Jurnal Didaktik Matematika, 3(1), 77-86.

Fuadi, R., Johar, R., \& Munzir, S. (2016). Peningkatkan Kemampuan Pemahaman Dan Penalaran Matematis Melalui Pendekatan Kontekstual. Jurnal Didaktik Matematika, 3(1), 47-54.

Herman, T. (2007). Pembelajaran berbasis Masalah untuk Meningkatkan Kemampuan Penalaran Matematis Siswa SMP. Yogyakarta State University.

Hijriani, L., Rahardjo, S., \& Rahardi, R. (2018). Deskripsi Representasi Matematis Siswa SMP dalam Menyelesaikan Soal PISA. Jurnal Pendidikan: Teori, Penelitian, dan Pengembangan, 3(5), 603-607.

Hijriani, L. (2018). Representasi Matematis Siswa SMP dan Kemampuan Matematikanya Ditinjau dari Taksonomi Bloom dalam Menyelesaikan Masalah Sistem Persamaan Linear Dua Variabel. Disertasi Dan Tesis Program Pascasarjana UM.

Kusumawardani, D. R., Wardono, W., \& Kartono, K. (2018). Pentingnya Penalaran Matematika dalam Meningkatkan Kemampuan 
Literasi Matematika. In PRISMA, Prosiding Seminar Nasional Matematika,1, 588-595.

Lestari, I., \& Andinny, Y. (2020). Kemampuan Penalaran Matematika Melalui Model Pembelajaran Methaporical Thinking Ditinjau dari Disposisi Matematis. Jurnal Elemen, 6(1), 112.

Ma'sum, A. (2014). Profil Kemampuan Penalaran Matematis Siswa dalam Menyelesaikan Soal Bangun Ruang Sisi Lengkung. Jombang: Prodi Pendidikan Matematika STKIP PGRI.

Mettes, C.T.W. (1979). Teaching and Learning Problem Solving in Science A General Strategy. International Journal of Science Education, 57(3), 882 - 885.

National Council of Teachers of Mathematics. (2000). Principles and Standards for School Mathematics. Virginia: NCTM.

Paranduri, I. H. (2018). Penerapan Model Pembelajaran Project Based Learning terhadap Peningkatan Kemampuan Berpikir Kritis dan Disposisi Matematis Siswa. JKPM (Jurnal Kajian Pendidikan Matematika), 3(2), 145-156.

Rosnawati, R. (2013). Kemampuan penalaran matematika siswa SMP Indonesia pada TIMSS 2011. In Prosiding Seminar Nasional Penelitian, Pendidikan dan Penerapan MIPA, Fakultas MIPA, Universitas Negeri Yogyakarta (Vol. 18).
Salim, N.D. (2015). Meningkatkan Kemampuan Berpikir Kritis Dan Penalaran Matematis Siswa Melalui Model Brain Based Learning. Jurnal Cakrawala Pendas, 1(1).

Subchan, et al. (2018). Buku Guru Matematika Kelas IX. Jakarta: Kemendikbud RI.

Sumartini, T. S. (2015). Peningkatan kemampuan penalaran matematis siswa melalui pembelajaran berbasis masalah. Mosharafa: Jurnal Pendidikan Matematika, 4(1), 1-10.

Suprihatiningsih, S. (2015). Penalaran Matematis Siswa Dalam Pemecahan Masalah Pada Materi Pokok Faktorisasi Bentuk Aljabar Di Kelas VIII SMP Negeri 1 Surakarta 